Jurnal Ilmu Pendidikan Fisika is licensed under

A Creative Commons Attribution-Non Commercial 4.0 International License.

\title{
Penerapan Three TIER-TeSt UNTUK IDENTIFIKASI KuANTITAS SiSWA YANG Miskonsepsi PAdA MATERi MAgnet
}

\author{
Reny Silviani ${ }^{1)}$, Riski Muliyani ${ }^{2)}$, Yudi Kurniawan ${ }^{3)}$ \\ 1) STKIP Singkawang, Singkawang, Indonesia \\ E-mail: silvianirenny@gmail.com \\ ${ }^{2)}$ STKIP Singkawang, Singkawang, Indonesia \\ E-mail: kikiriski1012@gmail.com \\ 3) STKIP Singkawang, Singkawang, Indonesia \\ E-mail: yudikurniawan1012@gmail.com
}

\begin{abstract}
Abstrak. Proses pembelajaran yang bersifat informative dan hanya ditekankan pada konsep teoritik saja dapat menyebabkan siswa kurang menguasai konsep ilmiah.Faktor yang menyebabkan rendahnya penguasaan konsep siswa adalah miskonsepsi. Miskonsepsi merupakan kekeliruan dalam memahami suatu konsep materi pembelajaran yang tidak akurat, yang dapat menyebabkan ketidaksesuaian antara konsep yang dimiliki pribadi dengan konsep ilmiah. Dengan adanya miskonsepsi yang terjadi, hal ini dapat menghambat siswa untuk menerima informasi yang baru, sehingga siswa menolak untuk mengubah miskonsepsinya menjadi konsep ilmiah. Penelitian ini bertujuan untuk mengidentifikasi mengenai kuantitas siswa yang miskonsepsi pada materi magnet. Penelitian ini merupakan penelitian deskriptif kuantitatif dengan teknik pengambilan sampel adalah purposive sampling.Instrumen penelitian yang digunakan adalah three tier-test. Penggunaan three tier-test yaitu untuk mengidentifikasi kuantita ssiswa yang miskonsepsi. Jawaban yang telah dianalisis, selanjutnya akan dihitung dalam bentuk persentase. Hasil dari penelitian menunjukkan bahwa terdapat 3 konsep distribusi atau sebaran miskonsepsi pada materi magnet, yaitu; 1 . Semua benda berwarna perak ditarik magnet; 2 . Tarikan magnet yang lebih besar pasti lebih kuat dari tarikan magnet yang kecil; 3. Semua logam dapat ditarik magnet.Miskonsepsi tertinggi terdapat pada konsep tarikan magnet yang lebih besar pasti lebih kuat dari tarikan magnet yang kecil. Diharapkan hasil dari penelitian ini dapat dijadikan referensi untuk mencari solusi dalam menurunkan kuantitas siswa yang miskonsepsik hususnya pada materi magnet.
\end{abstract}

Kata Kunci: Three Tier-Test, Kuantitas Siswa yang Miskonsepsi, Miskonsepsi

\section{PENDAhuluan}

Proses pembelajran yang bersifat informatif dan hanya terfokus pada buku teks, rumus, dan hafalan atau pada konsept eoritik saja dapat menyebabkan siswa kurang menguasai konsep ilmiah. Faktor lainnya yang menyebabkan terjadinya rendahnya penguasaankonsep pada siswa adalah miskonsepsi. Menurut Kurniawan dan Suhandi (2015), miskonsepsi adalah kegagalan dalam menghubungkan atau menjelaskan peristiwa yang ada di sekitar dengan konsep ide mereka sendiri [1]. Menurut Muliyani dan Kaniawati (2015), miskonsepsi dapat dirujuk atau dilihat pada konsep yang tidak cocok dengan konsep ilmiah. Miskonsepsi yang terjadi pada siswa harus segera diatasi [2]. Diperlukan suatu upaya yang dapat mengubah konsepsi siswa yang keliru menjadi sesuai dengan konsep ilmiah. Secara garis besar langkah yang digunakan membantu mengatasi miskonsepsi yaitu salah satunya adalah mencari solusi dengan memberiperlakuan yang sesuai untuk mengatasi miskonsepsi tersebut [3]

Penelitian ini bertujuan untuk mengidentifikasi mengenai kuantitas siswa yang miskonsepsi pada materi magnet. Hasil penelitian Suparno (2005), bentuk miskonsepsi yang ditemukan pada siswa yaitu: 1) semua benda berwarna perak ditarik magnet; 2) tarikan magnet yang lebih besar pasti lebih kuat dari tarikan magnet yang kecil; dan 3) semua logam dapat ditarik magnet [3].

\section{METODE}

Jenis penelitian yang digunakan pada penelitian ini adalah deskriptif kuantitatif dan hasil dari penelitian ini adalah gambaran mengenai jumlah kuantitas siswa yang miskonsepsi pada materi magnet. Populasi dalam penelitian ini adalah seluruh siswa kelas $\mathrm{X}$ di salah satu SMA Negeri Kota Singkawang. Teknik pengambilan sampel dalam penelitian ini 


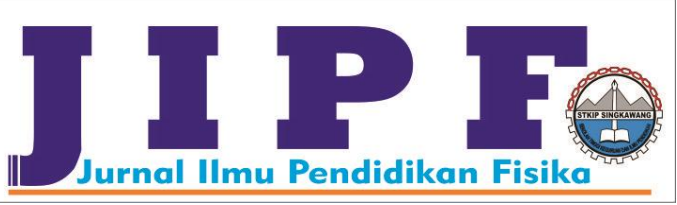

adalah purposive sampling, teknik penentuan sampel dengan pertimbangan tertentu yaitu siswa yang telah mempelajari materi magnet. Jumlah sampel pada penelitian ini berjumlah 28 orang siswa. Terdapat beberapa keputusan dalam three tier-test. Berikut adalah table keputusan dalam three tier-test yang diadopsi dari Kurniawan, et.al [4].

TABEL 1

KEPUTUSAN DALAM THREE TIER-TEST

\begin{tabular}{llll}
\hline Keputusan & Tier $\mathbf{1}$ & Tier 2 & Tier 3 \\
\hline Konsep Ilmiah & Benar & Benar & Yakin \\
\hline Miskonsepsi & Benar & Salah & Yakin \\
\hline Miskonsepsi & Salah & Benar & Yakin \\
\hline Miskonsepsi & Salah & Salah & Yakin \\
\hline Guess & Benar & Salah & TidakYakin \\
\hline Guess & Salah & Benar & Tidak Yakin \\
\hline Lucky Guess & Benar & Benar & TidakYakin \\
\hline Lack of knowledge & Salah & Salah & Tidak Yakin
\end{tabular}

Penggunaan three tier-test dapat mempermudah dalam mengungkapkan miskonsepsi yang terjadi pada siswa. Berikut merupakan distribusi data mengenai sebaran miskonsepsi dapat dilihat pada Tabel 2

TABEL 2

SEBARAN MISKONSEPSI PADA SOAL

\begin{tabular}{cl}
\hline $\begin{array}{c}\text { No } \\
\text { Konsep }\end{array}$ & \multicolumn{1}{c}{ Miskonsepsi } \\
\hline 1 & Semua benda berwarna perak ditarik magnet \\
\hline 2 & $\begin{array}{l}\text { Tarikan magnet yang lebih besar pasti lebih kuat dari } \\
\text { tarikan magnet yang kecil }\end{array}$ \\
\hline 3 & Semua logam dapat ditarik magnet \\
\hline
\end{tabular}

\section{HASIL DAN PEMBAHASAN}

Setiap jawaban siswa kemudian akan dianalisis dan disajikan pada diagram berikut. Persentase kuantitas siswa yang miskonsepsi terdapat pada Gambar 1 berikut.

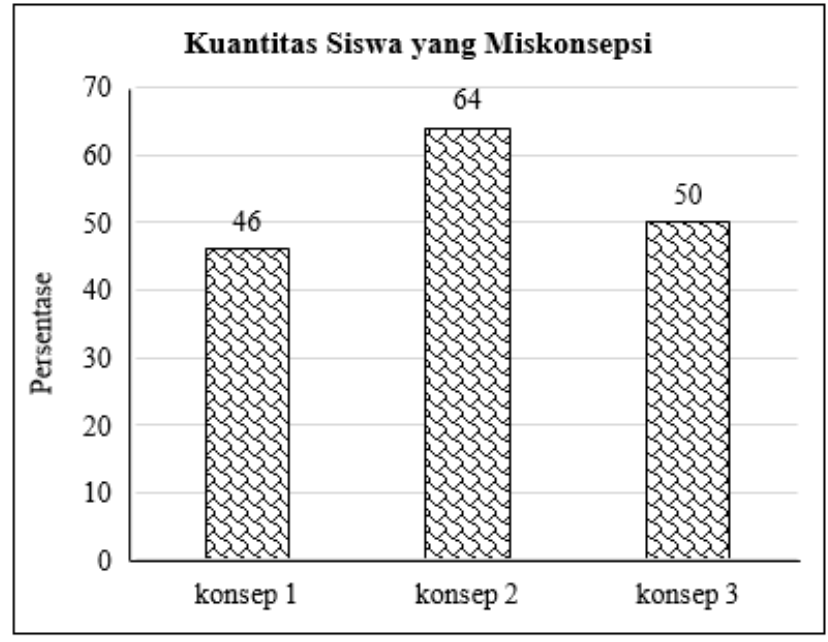

Gambar. 1 Persentase Kuantitas Siswa yang Miskonsepsi

Berdasarkan gambar di atas, kuantitas siswa yang miskonsepsi tertinggi yaitu pada konsep 2, tarikan magnet yang lebih besar pasti lebih kuat dari tarikan magnet yang
Jurnal Ilmu Pendidikan Fisika

Volume 2 Number 1 month March 2017. Page 10-11 p-ISSN: 2477-5959 e-ISSN: 2477-8451

kecil. Identifikasi kuantitas siswa yang miskonsepsi pada penelitian ini menggunakan three tier-test. Hasil data yang dianalisis, persentase miskonsepsi pada konsep 1, yaitu $46 \%$ dengan miskonsepsi semua benda berwarna perak ditarik magnet. Persentase pada konsep 2,yaitu 64\% dengan miskonsepsi tarikan magnet yang lebih besar pasti lebih kuat dari magnet yang kecil, sedangkan persentase pada konsep 3 , yaitu 50\% dengan miskonsepsi semua logam dapat ditarik magnet.

\section{KESIMPULAN}

Berdasarkan hasil analisis data yang dilakukan dapat disimpulkan bahwa miskonsepsi konsep 1 adalah $46 \%$ dengan kategori rendah pada miskonsepsi "semua benda berwarna perak ditarik magnet". Miskonsepsikonsep 2 adalah 64\% dengan kategori tinggi pada miskonsepsi "tarikan magnet yang lebih besar pasti lebih kuat dari tarikan magnet yang kecil". Sedangkan miskonsepsi konsep 3 adalah 50\% dengan kategori tinggi pada miskonsepsi "semua logam dapat ditarik magnet".

Diharapkan hasil dari penelitian ini dapat dijadikan referensi untuk penelitian selanjutnya dan ditemukan penyebab serta solusi dari miskonsepsi tersebut

\section{UCAPAN TERIMAKASIH}

Ucapan terima kasih diberikan kepada STKIP Singkawang yang telah memfasilitasi penulis sehingga tulisan ini dapat dipublikasikan dalam berkala ilmiah STKIP Singkawang.

\section{DAFTAR PUSTAKA}

[1] Kurniawan, Yudi dan Suhandi, Andi, "The Three-Tier Test for Identification TheQuantity of Student's Misconception on Newton's First Law". Global Illuminators Publishing. Vol 2, 2015.

[2] Muliyani, Riski dan Kaniawati, Ida, "Identification of Quantity Student's Misconception on Hydrostatic Pressure With Three Tier-Test". Global Illuminators Publishing. Vol 2, 2015.

[3] Suparno, Paul, Miskonsepsi dan Perubahan Konsep Dalam Pendidikan Fisika, Jakarta: PT Grasindo, 2005.

[4] Kurniawan, Yudi, Suhandi, Andi dan Hasanah, Lilik, "The Influence of Implementations of Interactive Lecture Demonstrations (ILD) Conceptual Change Oriented Toward The Decreasing of The Quantity Students That Misconceptions on The Newton's First Law". AIP Conference Proceedings, 2016. 